\title{
Managerial Pay and Governance in American Nonprofits
}

\author{
KEVIN F. HALLOCK*
}

This article examines the compensation of top managers of nonprofits in the United States using panel data from tax returns of the organizations from 1992 to 1996. Studying managers in nonprofits is particularly interesting given the difficulty in measuring performance. The article examines many areas commonly studied in the executive pay (within for-profit firms) literature. It explores pay differences between for-profit and nonprofit firms, pay variability within and across nonprofit industries, managerial pay and performance (including organization size and fund raising) in nonprofits, the effect of government grants on managerial pay, and the relationship between boards of directors and managerial pay in nonprofits.

Although there has BeEn Substantial work on EXeCutive COMPENSATION IN THE FOR-PROFIT WORLD (Murphy 1999), very little academic work has focused on the nonprofit sector [see Oster (1998) for a recent exception]. This article examines several areas in the compensation of managers of nonprofits, including pay levels, pay dispersion, pay for performance, the effects of government grants, and governance, using detailed panel data from the Internal Revenue Service (IRS) on more than

*Department of Economics and Institute of Labor \& Industrial Relations, University of Illinois at Urbana-Champaign. E-mail: hallock@uiuc.edu. I am grateful for helpful discussions with Orley Ashenfelter, David Balan, Marianne Bertrand, Sherrilyn Billger, Jan Brueckner, Peter Cappelli, Ken Chay, John Core, John DiNardo, Todd Fister, Earl Grinols, Wayne Guay, Wally Hendricks, Roger Koenker, Kathy Pettit, and Mary Taber on issues related to this article. The editor and three referees also made very helpful suggestions. I also thank participants in seminars at Brigham Young University, The University of Illinois, The University of Pennsylvania, and The Princeton University for helpful comments. The American Compensation Association provided financial support. The views expressed are solely the author's and do not reflect the views or opinions of the American Compensation Association. 
30,000 manager-years from 1992 to 1996. It is particularly difficult to understand incentives for managers in situations like nonprofits where performance is unusually difficult to measure or quantify (Weisbrod 1989). This study provides an empirical analysis of several of the issues.

For a variety of reasons nonprofits provide an interesting context in which to study the pay of managers during this period. First, nonprofits are an important part of the economy. There are more than 1 million nonprofits in the United States. They employ more than 10 percent of all workers and account for about 6 percent of gross national product (GNP) (Bowen et al. 1994). Second, although there has been increased scrutiny from the IRS over the pay of managers of firms, recent legislation has focused on the pay of top managers of charities in the United States (Taxpayer Bill of Rights 2, 1996). This new law not only requires organizations to carefully document how much they pay top managers, but it also requires the boards of the charities to be able to document how the salaries of their chiefs are determined. If the salaries are found to be higher than expected and higher than those found in similar charities, the heads could be fined and required to return the amount by which they were overpaid. Moreover, the members of the boards of directors of these charities also could be fined if pay levels of the top managers are found to be in question. The problem with this legislation is that there are no strong guidelines for applying these laws. The third reason nonprofits are an interesting context in which to study compensation is that there is a theoretical literature that deals, in part, with how managers in nonprofits may be paid, but there is almost no empirical work in the area.

The data needed to study managerial pay in nonprofits has become available only recently. This article uses panel data on nonprofits and their top managers from a large sample of IRS tax returns of thousands of nonprofits for each year from 1992 to 1996 (inclusive). I also use a sample of top executives of firms collected from Standard \& Poor's EXECUCOMP for comparison.

Clearly, nonprofits are different from for-profit firms (see Hansmann 1980, 1996; Mirvis and Hackett 1983; Steinberg 1990a, 1990b). However, for at least two reasons it seems natural to study the compensation of those at the top of nonprofits in the same way as the compensation of senior executives of for-profit firms. First, both types of top managers are quite visible and clearly focal people within their organizations. Second, recent scrutiny of nonprofits from the IRS and others is similar to that faced by large firms in the United States. We know a great deal about the pay of executives in large firms but very little about compensation within nonprofits.

Researchers have studied compensation for well-educated people in the nonprofit sector but have not concentrated primarily on top managers. For 
example, Weisbrod (1983) suggested that lawyers who work in the "public interest" sector have different preferences from those who work in private practices, and Preston (1989) found that the nonprofit/for-profit wage differential was negative for many groups of workers but statistically more negative for managers and professionals. She suggested that the managers and professionals were more "closely tied to social benefit provision" in the organizations and therefore were more likely to "donate" wages to the nonprofits by accepting lower wages for similar work. ${ }^{1}$ Both these articles study differences in pay levels across the for-profit and nonprofit sectors generally. Neither studies managers or directors, nor do they consider such a volume of data across such a wide variety of organizations.

In this article I use panel data from IRS returns on 32,146 organizationyears to examine several issues related to top executives in nonprofit organizations. The first section briefly describes the nonprofit sector and some reasons we might expect pay to be different in nonprofits than in forprofit firms. The second section introduces the unique data and outlines an industry classification system known as the National Taxonomy of Exempt Entities (NTEE), which is similar to the Standard Industrial Classification (SIC) system used for firms. The second section also includes basic summary statistics on the pay of managers and directors by NTEE. We know from studying large for-profit firms that there is a well-documented link between chief executive officer (CEO) pay and organization size, but evidence for a link between other for-profit performance measures and CEO pay is mixed. The third section, therefore, is a discussion of measures of performance (including organization size) and whether there is a link between managerial pay and performance in nonprofits. The fourth section studies the connection between government grants and managerial pay in nonprofits and examines whether managerial pay increases in years when nonprofits get larger grants from the government. The fifth section examines governance and whether the size of the board of directors affects managerial pay in nonprofits. Finally, the last section offers concluding comments.

I find that managerial pay in nonprofits is substantial and varies within and across organizations. I also document certain possible measures of performance of the managers of nonprofits; however, evidence linking pay to performance is only robust when performance is measured as some function of organization size. Also, although in the cross section it appears that nonprofits with larger government grants pay their managers more, this is not true within organizations. Finally, I find that the larger the number of paid board members, the lower is the pay of the top officers and other staff.

\footnotetext{
${ }^{1}$ Also see Preston $(1990,1994)$ for interesting discussion of women in the nonprofit sector.
} 
Structure and Uniqueness of the Nonprofit Sector

Distinct Institutional Features. This section places 501c(3) (charitable) nonprofits into the larger context of all nonprofit organizations. ${ }^{2}$ These institutional features are discussed in order to provide a background for the discussion of managerial pay in nonprofits that follows.

In order to become officially designated as a nonprofit, an organization must file forms with the IRS. Such organizations do not have to pay taxes, although if they have greater than $\$ 25,000$ in annual net revenue, they must file IRS Form 990 (described in more detail in the data section below). Among the 28 possible groupings for nonprofits, by far the most common designation is 501c(3), "Charitable and Religious." $501 \mathrm{c}(3)$ organizations are considered charitable because, according to the IRS, they serve "broad public purposes include[ing] educational, religious, scientific, and literary activities, among others, as well as the relief of poverty and other public benefit actions" (Stevenson, Pollak, and Lampkin 1997). Table 1 shows that of the roughly 1 million nonprofit organizations in the United States in 1992 and 1996, approximately half were $501 \mathrm{c}(3)$ organizations. $501 \mathrm{c}(3)$ nonprofits have the added benefit that contributions to the organization are deductible to the contributor.

There are at least two key features of nonprofits that distinguish them from for-profit organizations. First, nonprofits inherently have a different bottom line in that they are not created to generate returns to their shareholders. Second is Hansmann's "nondistribution constraint." Hansmann $(1980,1996)$ notes that while nonprofit organizations are free to make profits, those profits cannot be distributed to those with formal control over the organization: "A nonprofit organization is, in essence, an organization that is barred from distributing its net earnings, if any, to individuals who exercise control over it, such as members, officers, directors, or trustees" (Hansmann 1980). However, this does not imply that nonprofit organizations cannot make profits in a technical sense; rather, "It is only the distribution of profits that is prohibited" (Hansmann 1980).

It is also worthwhile considering why some organizations might form as nonprofits. Hansmann outlines several reasons. The first is that the buyer and the recipient of goods and services are not always the same person. For example, people are more likely to donate funds to a relief organization

\footnotetext{
${ }^{2}$ The first part of this discussion is based on Stevenson, Pollak, and Lampkin (1997). Also see Bowen et al. (1994) for a detailed description of charitable nonprofits.
} 


\section{TABLE 1}

TAX-EXempt Organizations Registered with the IRS IN 1992 AND 1995

\begin{tabular}{|c|c|c|c|}
\hline Section & & Number in 1992 & Number in 1995 \\
\hline $501(\mathrm{c})(1)$ & $\begin{array}{l}\text { Corporations Organized Under Acts } \\
\text { of Congress }\end{array}$ & 9 & 9 \\
\hline $501(\mathrm{c})(2)$ & Titleholding Corporations & 6,529 & 7,025 \\
\hline $501(c)(3)$ & Charitable and Religious & 546,100 & 626,226 \\
\hline $501(\mathrm{c})(4)$ & Social Welfare & 142,673 & 139,451 \\
\hline $501(\mathrm{c})(5)$ & Labor, agricultural organizations & 71,012 & 66,662 \\
\hline $501(\mathrm{c})(6)$ & Business leagues & 70,871 & 75,695 \\
\hline $501(\mathrm{c})(7)$ & Social and recreational clubs & 64,681 & 65,501 \\
\hline $501(\mathrm{c})(8)$ & Fraternal and beneficiary societies & 93,544 & 92,115 \\
\hline $501(\mathrm{c})(9)$ & Voluntary employees' beneficiary associations & 14,986 & 14,681 \\
\hline $501(\mathrm{c})(10)$ & Domestic fraternal beneficiary societies & 21,415 & 21,046 \\
\hline $501(\mathrm{c})(11)$ & Teachers' retirement funds & 10 & 11 \\
\hline $501(\mathrm{c})(12)$ & Benevolent life insurance associations & 6,103 & 6,291 \\
\hline $501(\mathrm{c})(13)$ & Cemetery companies & 9,025 & 9,433 \\
\hline $501(\mathrm{c})(14)$ & State chartered credit unions & 5,559 & 5,225 \\
\hline $501(\mathrm{c})(15)$ & Mutual insurance companies & 1,157 & 1,185 \\
\hline $501(\mathrm{c})(16)$ & Corporations to finance crop operations & 23 & 23 \\
\hline $501(\mathrm{c})(17)$ & Supplemental unemployment benefit trusts & 625 & 583 \\
\hline $501(\mathrm{c})(18)$ & Employee funded pension trusts & 8 & 3 \\
\hline $501(\mathrm{c})(19)$ & War veterans' organizations & 28,096 & 30,828 \\
\hline $501(\mathrm{c})(20)$ & Legal service organizations & 217 & 141 \\
\hline $501(\mathrm{c})(21)$ & Black lung trusts & 23 & 25 \\
\hline $501(\mathrm{c})(22)$ & Multi-employer pension plans & 0 & 0 \\
\hline $501(\mathrm{c})(23)$ & Veterans' associations founded prior to 1880 & 2 & 2 \\
\hline $501(\mathrm{c})(24)$ & Trusts described in section 4049 of ERISA & 1 & 1 \\
\hline $501(\mathrm{c})(25)$ & Holding companies for pensions, etc. & 290 & 638 \\
\hline $501(\mathrm{~d})$ & Religious and apostolic organizations & 92 & 107 \\
\hline $501(\mathrm{e})$ & Cooperative hospital service organizations & 68 & 61 \\
\hline $501(\mathrm{f})$ & $\begin{array}{l}\text { Cooperative service organizations of } \\
\text { operating educational orgs. }\end{array}$ & 1 & 1 \\
\hline 521 & Farmers' cooperatives & 2,086 & 1,810 \\
\hline TOTAL & & $1,085,206$ & $1,164,779$ \\
\hline
\end{tabular}

Source: Adapted from Stevenson, Pollak, and Lampkin, State Nonprofit Almanac 1997: Profiles of Charitable Organizations, p. 3. Original source: U.S. Internal Revenue Service, Annual Report and IRS Databooks, various editions.

organized as a nonprofit because they know that the managers are less likely to abscond with the residual money. Another reason that an organization may form as a nonprofit comes out of the idea of public goods (Hansmann 1980). The fact that one person enjoys the services of a public good does not preclude others from doing the same. For example, donors are more likely to contribute to nonprofit public radio stations because they are more likely to believe that the funds will be used for programming rather than for the private benefit of the managers. Museums and operas are similar in that they practice "voluntary price discrimination" (Hansmann 1980) by offering 
low-priced seats, but those who can afford to contribute do so with the knowledge that the residual money cannot be distributed to those in control. Hansmann (1980) also describes "implicit loans" in higher education, where students are more likely to donate money back to their nonprofit colleges when they feel that those in charge cannot keep the money for themselves.

Another interesting and important example of an institution that optimally may form as a nonprofit is a nursing home or day-care center (Weisbrod and Schlesinger 1986). Parents (in the case of a day-care center) and children (in the case of a nursing home) are more likely to place their loved ones in the care of institutions organized as nonprofits because they believe that the additional dollar is more likely spent on quality care, food, etc., and not on the well-being of the manager.

Reasons Why Pay Levels for Managers of Nonprofits May Be Different. The first possible reason for differences in pay between employees of nonprofit organizations and for-profit firms was presented by Preston (1989), and some of her findings may be applied to managers as I do here. The idea has to do with "labor donations" and the fact that workers may trade lower pay for higher social benefits. The limiting case of labor donations is volunteer labor, where workers are paid nothing for the time they donate to an organization. If labor donations are at work, it is expected that wages for similar workers will be lower in nonprofits than in for-profit firms. ${ }^{3}$

Another possible reason for differences in pay comes from the screening hypothesis of Hansmann (1980) and is related to the choice of organizational form described earlier. Hansmann (1980) examined a simple model in which there are two types of managers. He suggested that if consumers are not good judges of the quality of a service provided by an organization, then some managers, by virtue of accepting lower wages, could make productive signals to the uninformed consumers, and "the nonprofit form may both restrain the managers of the organization, whatever their personal desires, from profiteering at the expense of the organization's patrons and may select as managers precisely that class of individuals whose preferences are most in consonance with the fiduciary role that the organization is destined to serve." In other words, heads of nonprofits essentially take lower wages to signal that donations will be used effectively.

Workers in nonprofits may accept lower wages in exchange for a host of pleasant amenities on their job, such as flexible hours, more stable job

\footnotetext{
${ }^{3}$ On the other hand, since managers in nonprofits are not constrained to keep wages low (as they might if in competition with a for-profit firm), they may push wages up because it is a pleasant and easy thing to do.
} 
prospects, and a slower pace of work (compensating differentials). ${ }^{4}$ An additional reason for lower pay in nonprofits may be the differences in returns to characteristics of managers and ability bias. Controlling for ability across sectors is beyond the scope of this article, although it is empirically testable if one had data on those individuals who switch management jobs between sectors.

\section{Data}

Primary Sample. The data I use in this article are from tax returns of $501 \mathrm{c}(3)$ tax-exempt organizations. The primary sample includes organizations filing Form 990 returns each year from 1992 to 1996 (inclusive). The original sample consists of 35,109 organization-years (on 10,539 unique organizations). I delete from the sample those organizations which have assets, expenses, revenue, program service expenses, grants, and other expenses or top officer, director, or trustee compensation that is missing or less than $\$ 1000$. I also dropped organizations that have negative values for management and general expenses, fund-raising expenses, or payments to affiliates. The financial criteria reduces the sample by 2175 observations (6.19 percent), and the compensation criteria reduces the sample by 788 observations (2.24 percent). These selection criteria reduce the sample to 32,146 organization-year observations over the 5 years (from 9776 unique organizations). Due to the selection criteria, the results are more generalizeable to larger nonprofits. These data come from the Statistics of Income (SOI) files of the IRS. See Stevenson, Pollak, and Lampkin (1997) for additional details on the data.

The IRS data contain a host of interesting information on the compensation of all officers and directors and of the top five nonofficer/director/ trustee employees. For each officer, director, trustee, or other "key employee," I have collected three measures of compensation: (1) base compensation, including "salary, fees, bonuses, and severance payments paid" (Internal Revenue Service 1996), (2) contributions to employee benefit plans and deferred compensation, including "medical dental and life insurance" (Internal Revenue Service 1996), and (3) expense account and other allowances, including "expense allowances or reimbursements that

\footnotetext{
${ }^{4}$ See Young (1984) and James and Rose-Ackerman (1986).

5"A 'key' employee is any person having responsibilities or powers similar to those of officers, directors, or trustees. The term includes the chief management and administrative officials of an organization (such as an executive director or chancellor) but does not include the heads of separate departments or smaller units within an organization" (Internal Revenue Service 1996).
} 
recipients must report as income on their separate income tax returns." Examples include amounts for which the recipient did not account to the organization or allowances that "were more than the payee spent on serving the organization." Organizations are required to include such payments as "the value of the personal use of housing, automobiles, or other assets owned or leased by the organization" (Internal Revenue Service 1996). Means and standard errors (in parentheses) for the sum of these three variables are reported in Table 2. (Breakdowns by industry and type of pay are reported in Table 3). The first officer or director earned, on average, $\$ 160,098$ (all financial data are reported in real 1996 dollars). A significant part of the analysis that follows will focus on the total compensation, which includes the sum of cash, benefits, and expense accounts of the top officer, director, or trustee and of the top nonofficer, nondirector, or nontrustee employee.

The average total compensation packages for the second and third highest paid officers and directors were $\$ 122,381$ and $\$ 111,530$, which are both substantially less than the average of $\$ 160,098$ reported for the top officer. The increase in average pay from position 3 to position 2 is 9.7 percent, and the increase in pay from position 2 to position 1 is 30.8 percent. This result (ever-increasing pay as one moves up the organizational hierarchy) is consistent with tournament theory (see Lazear and Rosen 1981). ${ }^{6}$ The top panel of Table 2 also reports mean total compensation for the three highest paid nonofficer, nondirector, or nontrustee employees. These are relatively lower, ranging from $\$ 112,659$ for the highest paid nonofficer, nondirector, or nontrustee employee to $\$ 83,127$ for the third highest paid nonofficer nondirector or nontrustee employee.

These numbers can be compared with the average compensation of a set of 6677 CEO-years collected from EXECUCOMP firms in the Standard \& Poor's (S \& P) 500, S \& P Midcap 400, and S \& P SmallCap 600 (1836 unique CEOs over 5 years from 1992 to 1996). The average salary and bonus for this sample of CEOs is $\$ 910,942$. The average compensation including salary, bonus, other annual compensation; total value of restricted stock granted; total value of stock options granted; long-term incentive payouts; and other is $\$ 2,183,024$. Clearly, on average, CEOs of large firms earn more than heads of nonprofits. It is important to note, however, that these firms are much larger than the sample of nonprofits (this will be explored further later in the article).

\footnotetext{
${ }^{6}$ However, the average pay increases are substantially higher in for-profit firms [e.g., Main, O'Reilly, and Wade (1993), who report the gain from the next-to-top to the top position to be on the order of 140 percent]. This might suggest that tournaments work less well in noprofits. There is further discussion of tournaments in nonprofits below.
} 
The data also include financial information such as total assets, total expenses, and revenue. The expenses are further broken down into several categories, including (1) program services expenses, which are "mainly those activities that the reporting organization was created to conduct and which, along with many activities commenced subsequently, form the basis of the organization's current exemption from tax,", (2) fund-raising expenses, which are "total expenses incurred in soliciting contributions, gifts, grants, etc.," (3) management and general expenses, which are the "organization's expenses for overall function and management, rather than for its direct conduct of fund-raising activities or program services," including "legal services, accounting, insurance, office management, personnel," and other expenses (Internal Revenue Service 1996), and (4) payments to affiliates. These data are reported in the second panel of Table 2. The assets of these organizations are substantial, averaging $\$ 62$ million. The average revenue is $\$ 60$ million, and the average expenses are $\$ 55$ million. A substantial fraction of the expenses are spent on program services ( $\$ 48$ million) and a relatively small fraction on fund raising.

I also have collected data on sources of support for the nonprofits under study. In particular, I have included information on three measures of outside support for the organizations as defined by the IRS: (1) public direct support, (2) public indirect support, and (3) government grants. Public direct support is the sum of "contributions, gifts, grants, and bequests that the organization received directly from the public" (Internal Revenue Service 1996). The average organization in the sample received $\$ 3.9$ million in public direct support each year during the sample period. Indirect public support includes "total contributions received indirectly from the public through solicitation campaigns conducted by federated fund-raising agencies and similar fund-raising organizations (such as the United Way organization and certain sectarian federations)" (Internal Revenue Service 1996). The average public indirect support each year during the sample period was $\$ 653,911$. Under the law, a government grant is "treated as a contribution if its primary purpose is to enable the donee to provide a service to, or maintain a facility for, the direct benefit of the public rather than to serve the direct and immediate needs of the grantor even if the public pays part of the expense of providing the service or facility" (Internal Revenue Service 1996). The average charity received roughly $\$ 3.2$ million in

\footnotetext{
7“'Program services include the organization's unrelated trade or business activities. For example, publishing a magazine is a program service even though the magazine contains both editorials and articles that further the organization's exempt purpose and advertising, the income from which is taxable as unrelated business income" (Internal Revenue Service 1996).
} 
TABLE 2

Sample Means and Standard Errors

\begin{tabular}{|c|c|c|c|c|c|c|}
\hline & All years & 1992 & 1993 & 1994 & 1995 & 1996 \\
\hline \multicolumn{7}{|c|}{ Compensation $^{a}$ (in 1996 dollars): } \\
\hline Officer/director 1 & $\begin{array}{l}160,098 \\
(1,465)\end{array}$ & $\begin{array}{l}153,591 \\
(2,149)\end{array}$ & $\begin{array}{l}163,463 \\
(6,376)\end{array}$ & $\begin{array}{l}162,832 \\
(2,176)\end{array}$ & $\begin{array}{l}161,708 \\
(2,028)\end{array}$ & $\begin{array}{l}158,511 \\
(1,879)\end{array}$ \\
\hline Officer/director 2 & $\begin{array}{l}122,383 \\
(803)\end{array}$ & $\begin{array}{l}117,820 \\
(1,567)\end{array}$ & $\begin{array}{l}124,071 \\
(2,287)\end{array}$ & $\begin{array}{l}124,179 \\
(1,710)\end{array}$ & $\begin{array}{l}124,396 \\
(1,843)\end{array}$ & $\begin{array}{l}121,073 \\
(1,512)\end{array}$ \\
\hline Officer/director 3 & $\begin{array}{l}111,531 \\
(1,052)\end{array}$ & $\begin{array}{l}107,206 \\
(1,665)\end{array}$ & $\begin{array}{l}114,901 \\
(4,365)\end{array}$ & $\begin{array}{l}112,685 \\
(1,693)\end{array}$ & $\begin{array}{l}112,657 \\
(1,690)\end{array}$ & $\begin{array}{l}110,046 \\
(1,537)\end{array}$ \\
\hline Employee 1 & $\begin{array}{l}112,659 \\
(956)\end{array}$ & $\begin{array}{l}113,837 \\
(2,148)\end{array}$ & $\begin{array}{l}110,762 \\
(1,557)\end{array}$ & $\begin{array}{l}112,699 \\
(1,736)\end{array}$ & $\begin{array}{l}115,066 \\
(2,743)\end{array}$ & $\begin{array}{l}111,102 \\
(2,097)\end{array}$ \\
\hline Employee 2 & $\begin{array}{l}92,242 \\
(635)\end{array}$ & $\begin{array}{l}93,946 \\
(1,432)\end{array}$ & $\begin{array}{l}93,968 \\
(1,280)\end{array}$ & $\begin{array}{l}92,715 \\
(1,405)\end{array}$ & $\begin{array}{l}91,099 \\
(1,346)\end{array}$ & $\begin{array}{l}90,230 \\
(1,533)\end{array}$ \\
\hline Employee 3 & $\begin{array}{l}83,127 \\
(973)\end{array}$ & $\begin{array}{l}88,875 \\
(4,756)\end{array}$ & $\begin{array}{l}85,531 \\
(1,173)\end{array}$ & $\begin{array}{l}81,813 \\
(1,242)\end{array}$ & $\begin{array}{l}81,075 \\
(1,232)\end{array}$ & $\begin{array}{l}79,849 \\
(1,288)\end{array}$ \\
\hline \multicolumn{7}{|l|}{ Financial (in 1996 dollars): } \\
\hline Total assets & $\begin{array}{l}61,964,460 \\
(1,781,228)\end{array}$ & $\begin{array}{l}57,280,090 \\
(3,159,508)\end{array}$ & $\begin{array}{l}56,820,660 \\
(2,988,762)\end{array}$ & $\begin{array}{l}58,963,050 \\
(3,162,180)\end{array}$ & $\begin{array}{l}65,972,750 \\
(4,664,855)\end{array}$ & $\begin{array}{l}68,478,680 \\
(4,715,875)\end{array}$ \\
\hline Total expenses & $\begin{array}{l}55,368,840 \\
(1,280,065)\end{array}$ & $\begin{array}{l}59,307,150 \\
(3,355,222)\end{array}$ & $\begin{array}{l}57,752,460 \\
(3,107,735)\end{array}$ & $\begin{array}{l}57,693,480 \\
(3,059,692)\end{array}$ & $\begin{array}{l}54,812,440 \\
(2,891,704)\end{array}$ & $\begin{array}{l}49,116,677 \\
(2,071,322)\end{array}$ \\
\hline Prog. serv. expense & $\begin{array}{l}48,229,380 \\
(1,209,423)\end{array}$ & $\begin{array}{l}51,866,760 \\
(3,197,091)\end{array}$ & $\begin{array}{l}50,555,760 \\
(2,951,454)\end{array}$ & $\begin{array}{l}50,275,490 \\
(2,903,213)\end{array}$ & $\begin{array}{l}47,718,860 \\
(2,740,749)\end{array}$ & $\begin{array}{l}42,433,480 \\
(1,894,644)\end{array}$ \\
\hline Fund raising expense & $\begin{array}{l}422,558 \\
(9,480)\end{array}$ & $\begin{array}{l}417,195 \\
(21,969)\end{array}$ & $\begin{array}{l}402,477 \\
(20,688)\end{array}$ & $\begin{array}{l}425,593 \\
(20,023)\end{array}$ & $\begin{array}{l}429,113 \\
(21,851)\end{array}$ & $\begin{array}{l}434,363 \\
(20,893)\end{array}$ \\
\hline Mgt. \& related expense & $\begin{array}{l}6,616,534 \\
(100,384)\end{array}$ & $\begin{array}{l}6,959,058 \\
(253,258)\end{array}$ & $\begin{array}{l}6,724,375 \\
(224,686)\end{array}$ & $\begin{array}{l}6,901,802 \\
(228,460)\end{array}$ & $\begin{array}{l}6,575,995 \\
(217,964)\end{array}$ & $\begin{array}{l}6,078,158 \\
(204,563)\end{array}$ \\
\hline Payments to affiliates & $\begin{array}{l}100,371 \\
(13,798)\end{array}$ & $\begin{array}{l}64,142 \\
(10,094)\end{array}$ & $\begin{array}{l}69,856 \\
(10,458)\end{array}$ & $\begin{array}{l}90,590 \\
(22,763)\end{array}$ & $\begin{array}{l}88,478 \\
(14,535)\end{array}$ & $\begin{array}{l}170,768 \\
(53,239)\end{array}$ \\
\hline Revenue & $\begin{array}{l}60,362,460 \\
(1,331,542)\end{array}$ & $\begin{array}{l}63,263,120 \\
(3,437,531)\end{array}$ & $\begin{array}{l}61,717,250 \\
(3,193,056)\end{array}$ & $\begin{array}{l}61,986,830 \\
(3,146,116)\end{array}$ & $\begin{array}{l}60,938,870 \\
(3,037,675)\end{array}$ & $\begin{array}{l}55,259,280 \\
(2,240,924)\end{array}$ \\
\hline
\end{tabular}




\begin{tabular}{|c|c|c|c|c|c|c|}
\hline \multicolumn{7}{|l|}{ Support (in 1996 dollars): } \\
\hline Public direct support & $\begin{array}{l}3,924,239 \\
(89,403)\end{array}$ & $\begin{array}{l}3,683,444 \\
(198,875)\end{array}$ & $\begin{array}{l}3,699,961 \\
(194,869)\end{array}$ & $\begin{array}{l}3,802,840 \\
(188,551)\end{array}$ & $\begin{array}{l}4,135,541 \\
(211,098)\end{array}$ & $\begin{array}{l}4,192,282 \\
(197,661)\end{array}$ \\
\hline Public indirect support & $\begin{array}{l}635,872 \\
(45,997)\end{array}$ & $\begin{array}{l}682,031 \\
(119,973)\end{array}$ & $\begin{array}{l}626,628 \\
(105,743)\end{array}$ & $\begin{array}{l}593,504 \\
(97,068)\end{array}$ & $\begin{array}{l}628,689 \\
(94,550)\end{array}$ & $\begin{array}{l}650,254 \\
(98,925)\end{array}$ \\
\hline Government grants & $\begin{array}{l}3,188,799 \\
(131,662)\end{array}$ & $\begin{array}{l}3,263,575 \\
(330,815)\end{array}$ & $\begin{array}{l}3,271,304 \\
(310,063)\end{array}$ & $\begin{array}{l}3,584,693 \\
(329,237)\end{array}$ & $\begin{array}{l}2,950,356 \\
(269,910)\end{array}$ & $\begin{array}{l}2,958,710 \\
(248,039)\end{array}$ \\
\hline \multicolumn{7}{|l|}{ Directors: } \\
\hline Uncompensated directors & $\begin{array}{c}20.462 \\
(0.154)\end{array}$ & $\begin{array}{l}19.232 \\
(0.385)\end{array}$ & $\begin{array}{c}20.448 \\
(0.378)\end{array}$ & $\begin{array}{c}20.799 \\
(0.371)\end{array}$ & $\begin{array}{c}20.630 \\
(0.316)\end{array}$ & $\begin{array}{c}20.958 \\
(0.290)\end{array}$ \\
\hline Compensated directors & $\begin{array}{c}4.061 \\
(0.027)\end{array}$ & $\begin{array}{c}4.076 \\
(0.067)\end{array}$ & $\begin{array}{c}3.967 \\
(0.061)\end{array}$ & $\begin{array}{c}4.189 \\
(0.066)\end{array}$ & $\begin{array}{c}4.093 \\
(0.061)\end{array}$ & $\begin{array}{c}3.991 \\
(0.054)\end{array}$ \\
\hline$N$ & 32146 & 5582 & 6082 & 6150 & 6817 & 7515 \\
\hline
\end{tabular}

NotE: Standard errors are in parentheses.

${ }^{a}$ Compensation defined as the sum of base pay, benefit plan contributions, plus expense accounts. These are broken into separate categories of pay (and by industry) in Table 3 .

SOURCE: IRS Tax Form 990 for individual organizations for 1992-1996. 
TABLE 3

Average Compensation of Top Employee and Top Officer and Director by Industry

\begin{tabular}{|c|c|c|c|c|c|c|c|}
\hline & \multirow[b]{2}{*}{$\begin{array}{l}\text { Number of } \\
\text { organizations }\end{array}$} & \multicolumn{3}{|c|}{ Top officer or director } & \multicolumn{3}{|c|}{ Top employee } \\
\hline & & Base pay & $\begin{array}{l}\text { Benefits } \\
\text { package }\end{array}$ & $\begin{array}{l}\text { Expense } \\
\text { account }\end{array}$ & Base pay & $\begin{array}{l}\text { Benefits } \\
\text { package }\end{array}$ & $\begin{array}{l}\text { Expense } \\
\text { account }\end{array}$ \\
\hline A. Arts, Culture, and Humanities & 2,030 & 117,605 & 10,412 & 2,391 & 69,367 & 4,786 & 542 \\
\hline $\begin{array}{l}\text { B. Educational Institutions and } \\
\text { Related Activities }\end{array}$ & 7,420 & 125,429 & 15,143 & 4,495 & 93,109 & 9,255 & 782 \\
\hline $\begin{array}{l}\text { C. Environmental Quality, Protection, } \\
\text { and Beautification }\end{array}$ & 423 & 98,384 & 9,113 & 1,607 & 51,366 & 4,705 & 292 \\
\hline D. Animal Related & 248 & 108,363 & 8,022 & 2,379 & 66,548 & 5,290 & 762 \\
\hline E. Health - General and Rehabilitative & 11,554 & 187,379 & 20,064 & 3,369 & 159,247 & 10,025 & 853 \\
\hline F. Mental Health, Crisis Intervention & 554 & 109,327 & 10,453 & 1,040 & 88,900 & 5,770 & 674 \\
\hline $\begin{array}{l}\text { G. Disease, Disorders, Medical } \\
\text { Disciplines }\end{array}$ & 424 & 159,196 & 15,918 & 2,821 & 117,375 & 10,355 & 757 \\
\hline H. Medical Research & 376 & 205,025 & 19,020 & 6,581 & 115,567 & 12,105 & 6,094 \\
\hline I. Crime, Legal-Related & 124 & 99,777 & 8,063 & 1,576 & 74,771 & 6,395 & 374 \\
\hline J. Employment, Job-Related & 257 & 108,255 & 11,972 & 2,656 & 49,052 & 3,993 & 1,292 \\
\hline K. Food, Agriculture, and Nutrition & 65 & 80,771 & 7,178 & 1,507 & 54,540 & 4,598 & 1,528 \\
\hline L. Housing, Shelter & 522 & 72,092 & 4,177 & 946 & 33,537 & 2,093 & 90 \\
\hline $\begin{array}{l}\text { M. Public Safety, Disaster } \\
\text { Preparedness, and Relief }\end{array}$ & 39 & 161,908 & 18,295 & 2,138 & 58,614 & 4,528 & 672 \\
\hline $\begin{array}{l}\text { N. Recreation, Sports. Leisure, } \\
\text { Athletics }\end{array}$ & 268 & 108,054 & 9,548 & 3,373 & 61,523 & 7,638 & 3,040 \\
\hline O. Youth Development & 383 & 89,048 & 8,297 & 1,119 & 45,404 & 4,359 & 426 \\
\hline $\begin{array}{l}\text { P. Human Services-Multipurpose } \\
\text { and Other }\end{array}$ & 3,262 & 94,874 & 8,195 & 1,660 & 54,051 & 4,396 & 419 \\
\hline $\begin{array}{l}\text { Q. International, Foreign Affairs, } \\
\text { and National Security }\end{array}$ & 402 & 126,566 & 14,535 & 3,121 & 83,901 & 9,421 & 2,634 \\
\hline R. Civil Rights, Social Action, Advocacy & 53 & 122,724 & 7,961 & 4,685 & 98,951 & 4,843 & 307 \\
\hline $\begin{array}{l}\text { S. Community Improvement, Capacity } \\
\text { Building }\end{array}$ & 388 & 115,513 & 9,632 & 2,139 & 54,093 & 5,433 & 499 \\
\hline
\end{tabular}


T. Philanthropy, Voluntarism, and

187

Grantmaking Foundations

U. Science and Technology Research Institutes, Services

V. Social Science Research Institutes,

Services

W. Public, Society Benefit: Multipurpose and Other

X. Religion Related, Spiritual Development

Y. Mutual/Membership Benefit

Organizations, Other

401

401

8,280

1,302

35,109

3,801

327

Z. Other

80

188,523

19,431

3,994

109,241

14,537

1,869

170

165,509

23,447

2,649

95,691

11,438

1,697

164,847

27,383

1,096

98,305

11,999

659

383

72,315

7,260

5,446

35,038

2,981

722

280

101,249

11,385

1,335

42,016

2,778

143

NotE: Total of 32,144 organization-years represented. The rows represent the 26 major categories of the National Taxonomy of Exempt Entities (NTEE).

SOURCE: IRS Tax Form 990 for individual organizations for years 1992-1996. 
government grants in a typical year during the sample. The last panel of Table 2 reports the average number of paid officers and directors (4) and the average number of uncompensated officers, directors, or trustees $(20){ }^{8}$

Industry Classifications. There is evidence in the literature on executive compensation in firms that executive pay levels vary by industry. For example, Joskow, Rose, and Shepard (1993) show that CEOs in regulated industries earn less than those in unregulated industries. Until recently, there has been no system such as SIC codes for firms to classify the substantially different missions of nonprofits even among those classified as 501c(3) organizations. However, the NTEE has been developed to help classify charitable nonprofits into specific groups.

The four-character NTEE codes are similar to SIC codes for firms. There are 26 "major groups" (listed in the left-hand column of Table 3), such as Arts, Culture, and Humanities and Educational Institutions and Related Activities, which comprise the first character of the codes. These 26 major groups can be generalized into 10 "major categories": (1) Arts, Culture, and Humanities, (2) Education, (3) Environment and Animals, (4) Health, (5) Human Services, (6) International, Foreign Affairs, (7) Public, Societal Benefit, (8) Religion Related, (9) Mutual/Membership Benefit, and (10) Unknown. Under each of these 26 groups are two digits of subcodes that make finer distinctions in organization type. The last of the four characters, the "common code," includes classifications such as Alliance Organizations, Management and Technical Assistance Services, and Public Education. There are a total of 645 unique subgroups in the NTEE. See Stevenson, Pollak, and Lampkin (1997:Appendix B), Hodgkinson (1990), Hodgkinson and Toppe (1991), Gronbjerg (1994), and Turner, Nygren, and Bowen (1992) for more details on the NTEE. In several parts of the remainder of this article I will control for industry effects by concentrating on the 26 major groups.

Table 3 reports some simple results of differences in compensation by major nonprofit industry type for the top officer, director, or trustee and for the top nonofficer, nondirector, or nontrustee employee. This table also separates total compensation into its three components: base pay, benefits package, and expense account. The pattern that the top officer or director earns more than the top nonofficer, nondirector, or nontrustee as reported in Table 2 is still evident in Table 3 (in fact, it is true in each group). It is also clear that there is substantial variation in the levels of compensation within

\footnotetext{
${ }^{8}$ Bowen (1994) has an interesting discussion about compensation of trustees in nonprofits as well as a more general discussion of leadership on boards of directors and comparisons between the for-profit and nonprofit sectors.
} 
the nonprofit sector (across NTEE classifications). For example, the average base pay for the top officer/director/trustee in the medical research sector (category H) was $\$ 205,025$, and the average in health, general and rehabilitative (category E) was $\$ 187,379$, whereas the average base pay for the top officer/director/trustee in the category of religion-related (category $\mathrm{X}$ ) was $\$ 72,315$, and the average in Housing, Shelter (category L) was $\$ 72,092$. There is also substantial variability in the value of the benefits package offered to the top officers/directors/trustees from a high of $\$ 27,383$ (Public, Society Benefit: Multipurpose and Other, category W) to a low of $\$ 4,177$ (Housing, Shelter). In addition, there is also significant variability in the expense account category, which ranged from a high of $\$ 6,581$ (Medical Research, category H) to a low of $\$ 946$ (Housing, Shelter). The ranges for the top non-officer/director/trustees employees are similarly striking. Although there has been only little work on specific industries within nonprofits [e.g., Ehrenberg, Cheslock, and Epifantseva (2000) for universities and Bertrand, Hallock, and Arnould (2000) for hospitals], continued work might help us to understand reasons for differences in pay across nonprofit industries.

\section{Pay for Performance in Nonprofits}

The relationship between performance of firms and the compensation of CEOs has been widely studied in for-profit firms, but little attention has been paid to nonprofits. In a few articles, however, Steinberg (1990a, 1990b) and Weisbrod (1989) examine incentive compensation for employees in nonprofits mostly from a theoretical point of view. We know that designing incentive compensation plans in for-profit firms is difficult (Lazear 1995), but it may be even more difficult to measure the performance of managers in nonprofits because these organizations are likely to be striving to create something much different from returns to shareholders. One feature that makes nonprofits distinct from for-profit organizations is the nondistribution constraint (described earlier). This nondistribution constraint does not imply, however, that employees cannot be paid based on incentives (see Abelson 1998; Steinberg 1990b).

A classic example of how difficult it is to measure performance for managers in the nonprofit sector is the case of a manager of a nursing home (Weisbrod and Schlesinger 1986). A manager could be paid based on the profits he or she accrues, but this gives him or her incentives to provide lower-quality care to the residents. The output sought by the board of the nursing home (say, trustworthiness) is difficult to observe. We could try to measure trustworthiness by using an easy-to-observe measure such as the mortality rate. However, 
this might induce management to admit residents who are mostly healthy, which is, no doubt, at odds with the mission of the board.

The literature on CEO pay and firm performance provides several common measures to test the top manager's performance, among which are stock returns and the change in market value or size of the firm. Since nonprofits are not owned by shareholders, there is no stock price or value of the nonprofits in the formal sense. The rest of this section is devoted to several possible measures of performance for managers in nonprofits.

Charity Size and Managerial Pay. A host of articles, including Murphy (1985), Finkelstein and Hambrick (1989), Kostiuk (1990), Lambert, Larker, and Weigelt (1991), and Rosen (1992), have documented a link between the size or scale of a firm and the pay of the CEO. ${ }^{9}$ Firm size has been measured in the executive pay literature by such variables as market value, assets, and number of employees. One reason why we would expect managers of nonprofits with more assets to earn more is that they have responsibility over a much larger number of people and resources. Larger organizations are more difficult to manage and therefore may require top executives with scarce (and expensive) human capital.

Table 4, panel A, reports the results of an empirical examination of this issue using the following very simple empirical specification:

$$
C_{i t}=S_{i t} \gamma+\alpha_{i}+e_{i t}
$$

where $C$ is the log of manager compensation, ${ }^{10} S$ is the log net ending assets of the organization, $i$ represents organizations, $t$ represents time in years, and $\left(\alpha_{i}+e_{i t}\right)$ is a composite error term containing possible permanent effects. ${ }^{11}$ The first column of Table 4, panel A, reports results from an ordinary least squares (OLS) regression of $\ln ($ total compensation) for the top officer, director, or trustee on $\ln ($ assets), a set of yearly indicator variables, and a constant for the nonprofits. Log assets is a naturally important measure of organization size of nonprofits (Salamon 1992). The coefficient on $\ln ($ assets)

\footnotetext{
${ }^{9}$ Also see Finkelstein and Hambrick (1996), Agarwal (1981), and Westphal and Zajac (1994).

${ }^{10}$ In Table 4, panel A, and in each of the tables that follow, the results are not influenced significantly by the specific definition of the dependent variable. That is, if I use $\ln$ (base pay), $\ln$ (base pay plus benefits), or $\ln$ (base pay plus benefits plus expense accounts), I get roughly the same results. I present results using the most comprehensive measure throughout the remainder of the article.

${ }^{11}$ It may seem reasonable to consider the compensation of a manager in the current period as a function of performance in a prior period. However, much of the time $t$ performance is obviously known prior to setting time $t$ pay. In addition to probably not being the correct specification from a conceptual point of view, an additional drawback of using lagged values, of course, is the loss of an additional year of data. In any event, repeating the analysis using lagged values of performance variables yields very similar results.
} 
TABLE 4

Managerial Pay and Performance in Nonprofit Organizations: Organization Size

\begin{tabular}{|c|c|c|c|c|c|c|}
\hline \multicolumn{7}{|c|}{ Panel A: Nonprofit organizations } \\
\hline & \multicolumn{6}{|c|}{ Dependent variable: $\ln ($ base pay + benefits + expense account $)$} \\
\hline & \multicolumn{3}{|c|}{ For top officer/director/trustee } & \multicolumn{3}{|c|}{ For top nonofficer/nondirector/nontrustee employee } \\
\hline & (1) & (2) & (3) & (4) & (5) & (6) \\
\hline Ln(assets) & $\begin{array}{l}0.218 * * * \\
(0.003)\end{array}$ & $\begin{array}{l}0.206^{* * * *} \\
(0.003)\end{array}$ & $\begin{array}{l}0.047 * * * \\
(0.010)\end{array}$ & $\begin{array}{l}0.173 * * * \\
(0.002)\end{array}$ & $\begin{array}{l}0.160 * * * \\
(0.002)\end{array}$ & $\begin{array}{l}0.010^{*} \\
(0.006)\end{array}$ \\
\hline NTEE indicators & No & Yes & No & No & Yes & No \\
\hline Org. indicators & No & No & Yes & No & No & Yes \\
\hline$R^{2}$ & 0.137 & 0.172 & 0.797 & 0.180 & 0.311 & 0.829 \\
\hline$N$ & 32146 & 32146 & 32146 & 25197 & 25197 & 25197 \\
\hline
\end{tabular}

SOURCE: IRS Tax Form 990 for individual organizations, years 1992-1996.

Panel B: For-profit organizations

Dependent variable: $\ln ($ total compensation for CEO)

(1)

(2)

(3)

$\begin{array}{llll}\text { Ln(assets) } & 0.256^{* * *} & 0.310^{* * *} & 0.242^{* * * *} \\ & (0.006) & (0.007) & (0.030) \\ \text { One-digit SIC } & \text { No } & \text { Yes } & \text { No } \\ \text { Firm indicators } & \text { No } & \text { No } & \text { Yes } \\ R^{2} & 0.237 & 0.294 & 0.713 \\ N & 6677 & 6677 & 6677\end{array}$

Note: Standard errors are in parentheses; *,*, and *** represent significance at the $0.10,0.05$, and 0.01 levels, respectively. Yearly indicators are included in all regressions. SOURCE: Standard \& Poor's EXECUCOMP. 
is $0.218(t=71)$. This return number is large and significantly positive, as expected, and is somewhat smaller than for CEOs of firms. ${ }^{12}$ This large effect, taken at face value, suggests that larger firms pay their top managers more. We know, though, that the compensation of managers varies by industry (recall Table 3), so in column 2 of Table 4, panel A, I also control for the industry in which the nonprofit operates. Even controlling for industry effects, firm size [measured as $\ln ($ assets $)$ ] is still a substantial and important contributor to top manager pay in this specification.

I performed a brief but similar analysis of the compensation of managers in firms for comparability using data on 6677 firm-years from 1992 to 1996 from the S \& P EXECUCOMP data described earlier. The dependent variable is the log of total compensation. The main independent variable $\ln$ (assets) (I also control for yearly time indicators) is also collected from EXECUCOMP. The regressions in Table 4, panel B, show that the return to assets is much higher in for-profit firms than in nonprofits. My results are consistent with those of other studies on CEO pay in firms. Using other measures of CEO pay for firms (e.g., just considering salary and bonus alone) as dependent variables yields similar results. Just as there is a well-documented link between the size or scale of a firm and CEO pay, there is a strong and positive link between the assets of a charity and the pay of its top manager, although it is somewhat weaker in nonprofits.

Clearly, however, firm size and industry effects do not fully explain top manager pay in this sample of nonprofits $\left(R^{2}\right.$ in column 2 of Table 4, panel $\mathrm{A}$, is only 0.172 ). We need, therefore, to control for the possibility that other characteristics of managers and organizations are confounding the relationship between firm size and managerial pay in nonprofits. To help remedy this situation, I make use of the 6 years of IRS panel data. If one is willing to assume that the source of endogeneity arises only through the permanent component of the error term $\alpha_{i}$ and not through the transitory component $e_{i t}$, then the standard fixed-effects estimate of the preceding equation will yield consistent estimates of the parameters. These results are displayed in the third column of Table 4, panel A, and show that, even controlling for organization fixed effects, the relationship between organization size and top manager pay remains. In other words, even within organizations, as organizations grow, managers are paid more. This same set of relationships holds for top nonofficer, nondirector, or nontrustee

\footnotetext{
${ }^{12}$ Perhaps firm size as measured by assets is more closely related to pay in for-profit organizations because size can be interpreted as the bottom line in for-profits but not in nonprofits. More work is needed in this area.
} 
employees in the right three columns of Table 4, panel A, although the coefficient estimates are smaller in each case.

As mentioned earlier, one problem with studying nonprofit organizations is their myriad of different potential missions. With for-profit firms, the goal or true measure of performance is increasing shareholder value, which many authors (e.g., Jensen and Murphy 1990) measure with firm market value (firm size). Table 5 relaxes the idea that the relationship between firm size and managerial pay should be the same across all different nonprofit

TABLE 5

Relationship Between Managerial Pay and Organization Size in Nonprofits: Dependent Variable is Log(total anNual COMPENSATION)

\begin{tabular}{llc}
\hline \hline & \multicolumn{2}{c}{$\begin{array}{c}\text { OLS regressions (no. of } \\
\text { organization effects) }\end{array}$} \\
\hline A. Arts, Culture, and Humanities & $0.245^{* * *}$ & $(0.010)$ \\
B. Educational Institutions and Related Activities & $0.209^{* * *}$ & $(0.006)$ \\
C. Environmental Quality, Protection, and Beautification & $0.135^{* * *}$ & $(0.026)$ \\
D. Animal Related & $0.348^{* * *}$ & $(0.029)$ \\
E. Health-General and Rehabilitative & $0.229^{* * *}$ & $(0.006)$ \\
F. Mental Health, Crisis Intervention & $0.178^{* * *}$ & $(0.018)$ \\
G. Disease, Disorders, Medical Disciplines & $0.184^{* * *}$ & $(0.030)$ \\
H. Medical Research & $0.280^{* * *}$ & $(0.039)$ \\
I. Crime, Legal-Related & $0.147^{* * *}$ & $(0.033)$ \\
J. Employment, Job-Related & $0.205^{* * *}$ & $(0.024)$ \\
K. Food, Agriculture, and Nutrition & $0.457^{* * *}$ & $(0.045)$ \\
L. Housing, Shelter & $0.147^{* * *}$ & $(0.021)$ \\
M. Public Safety, Disaster Preparedness, and Relief & $0.318^{* * *}$ & $(0.102)$ \\
N. Recreation, Sports. Leisure, Athletics & $0.190^{* * *}$ & $(0.032)$ \\
O. Youth Development & $0.280^{* * *}$ & $(0.019)$ \\
P. Human Services-Multipurpose and Other & $0.144^{* * *}$ & $(0.008)$ \\
Q. International, Foreign Affairs, and National Security & $0.079^{* * *}$ & $(0.030)$ \\
R. Civil Rights, Social Action, Advocacy & $0.199^{* * *}$ & $(0.050)$ \\
S. Community Improvement, Capacity Building & $0.058^{* *}$ & $(0.030)$ \\
T. Philanthropy, Voluntarism, and Grantmaking Foundations & $0.217^{* * *}$ & $(0.016)$ \\
U. Science and Technology Research Institutes, Services & $0.234^{* * *}$ & $(0.031)$ \\
V. Social Science Research Institutes, Services & $0.247^{* * *}$ & $(0.078)$ \\
W. Public, Society Benefit: Multipurpose and Other & $0.159^{* *}$ & $(0.064)$ \\
X. Religion Related, Spiritual Development & $0.156^{* * *}$ & $(0.025)$ \\
Y. Mutual/Membership Benefit Organizations, Other & $0.327^{* * *}$ & $(0.051)$ \\
Z. Other & $0.199^{* * *}$ & $(0.041)$ \\
\hline Nor & &
\end{tabular}

NoTE: Entries in table are coefficients on $\log$ (net ending assets) in compensation regression. Total of 32,146 organization years represented. The rows represent the 26 major categories of the National Taxonomy of Exempt Entities (NTEE). Yearly indicators are included in all regressions. ${ }^{*}, * *$, and $* * *$ represent significance at the $0.10,0.05$, and 0.01 levels, respectively.

SOURCE: IRS Tax Form 990 for individual organizations for years 1992-1996. 
industries while retaining the idea that net ending assets are an appropriate measure of size for each organization. ${ }^{13}$ This table represents the results for a set of regressions where the log of total compensation of the top officer, director, or trustee is regressed on log net ending assets and a set of annual time indicators by NTEE industry. It is clear that within each industry the relationship between organizational size and managerial pay is positive and significant. When individual organization fixed effects are controlled for (not reported in the tables), most industries have a relationship between firm size and managerial pay that is not statistically different from zero. This may reflect the fact that the samples are relatively small within industries.

Clearly, organizational size is strongly linked with top manager pay. The effect is tempered substantially when organization fixed effects are controlled for. Oster (1998) compares the relationship between managerial pay in nonprofits and organization size in various ways across selected industries such as hospitals, social service organizations, and foundations. In five separate samples of between 31 and 95 observations, she finds coefficients on measures of size such as $\log$ (assets) in a managerial pay regression in the range of 0.067 to 0.376 . Oster's (1998) work is very informative but based on limited samples and is only cross-sectional. She therefore cannot consider changes within organizations using organizationspecific effects. ${ }^{14}$

Other Measures of Performance. Although it is clear that firm size is strongly related to managerial pay in nonprofits (even within organizations), it is useful to investigate whether there might be other measures. Another possible choice is the fraction of expenses spent on program services, a measure on which some groups of nonprofits seem to concentrate. $^{15}$ Each column of Table 6 represents the results from a different OLS regression. Columns 1 through 3 report results when the dependent variable is $\log$ (total compensation for the top officer, director, or trustee). Columns 4 through 6 give the results when the dependent variable is $\log ($ total compensation of the top nonofficer, nondirector, or nontrustee). The regressions also control for $\ln ($ assets $)$ and yearly time indicators. In the

\footnotetext{
${ }^{13}$ Young (1984) examines compensation of nonprofit employees in various nonprofit industries, including higher education, health care, and social services. His work suggests that there may be different pay structures in different nonprofit industries.

${ }^{14}$ I cannot identify individual officers or employees by name, so I do not know when there is management turnover.

${ }^{15}$ The Council of Better Business Bureaus publishes a booklet entitled, Standard for Charitable Solicitations. Among the recommendations is that "A reasonable percentage of income from all sources shall be applied to programs and activities directly related to the purpose for which the organization exists" (Council of Better Business Bureaus undated).
} 
TABLE 6

Managerial Pay and Performance in Nonprofit Organizations:

Performance Measured as Program Service Expense as Fraction of TOTAL EXPENSE

\begin{tabular}{|c|c|c|c|c|c|c|}
\hline & \multicolumn{6}{|c|}{ Dependent variable: $\ln ($ base pay + benefits + expense account $)$} \\
\hline & \multicolumn{3}{|c|}{ For top officer/director/trustee } & \multicolumn{3}{|c|}{$\begin{array}{c}\text { For top nonofficer/nondirector/ } \\
\text { nontrustee employee }\end{array}$} \\
\hline & (1) & $(2)$ & (3) & (4) & $(5)$ & $(6)$ \\
\hline (Prog. expense)/total expense & $\begin{array}{l}0.098 * * * \\
(0.036)\end{array}$ & $\begin{array}{l}0.032 \\
(0.036)\end{array}$ & $\begin{array}{l}-0.025 \\
(0.048)\end{array}$ & $\begin{array}{l}0.589 * * * \\
(0.027)\end{array}$ & $\begin{array}{l}0.381^{* * *} \\
(0.025)\end{array}$ & $\begin{array}{l}0.033 \\
(0.035)\end{array}$ \\
\hline Ln(assets) & $\begin{array}{l}0.217 * * * \\
(0.003)\end{array}$ & $\begin{array}{l}0.206 * * * \\
(0.003)\end{array}$ & $\begin{array}{l}0.048 * * * \\
(0.009)\end{array}$ & $\begin{array}{l}0.171 * * * \\
(0.002)\end{array}$ & $\begin{array}{l}0.159^{* * *} \\
(0.002)\end{array}$ & $\begin{array}{l}0.010^{*} \\
(0.006)\end{array}$ \\
\hline NTEE indicators & No & Yes & No & No & Yes & No \\
\hline Org. indicators & No & No & Yes & No & No & Yes \\
\hline$R^{2}$ & 0.137 & 0.172 & 0.797 & 0.196 & 0.317 & 0.829 \\
\hline$N$ & 32146 & 32146 & 32146 & 25197 & 25197 & 25197 \\
\hline
\end{tabular}

NotE: Measure of performance (program service expense)/(total expense). Standard errors are in parentheses. *, **, and $* * *$ represent significance at the $0.10,0.05$, and 0.01 levels, respectively. Yearly indicators are included in all regressions.

SOURCE: IRS Tax Form 990 for individual organizations, years 1992-1996.

simple cross section for the top officer, director, or trustee, it is clear that higher levels of expenses going to program services are associated with higher pay (the coefficient estimate is 0.098). This result does not hold when we control for NTEE effects in column 2 or when we control for organization fixed effects in column 3.

Columns 4, 5, and 6 examine the compensation of the top nonofficer, nondirector, or nontrustee employee, and the results differ somewhat. In the simple cross section, the link between performance and pay is much stronger (0.591), and the result is still significant when 26 NTEE industry classifications are controlled for. However, within an organization (controlling for organization fixed effects), there is no link between top nonofficer, nondirector, or nontrustee pay and this measure of performance (column 6). ${ }^{16}$

Since the performance results are not particularly robust, it seems reasonable to investigate them further. Therefore, I reran the regressions from Table 6 by NTEE (industry) classification (26 possibilities) while still accounting for individual organization fixed effects (I have not reported the

\footnotetext{
${ }^{16}$ One possible reason for this is that there is little variation in the performance variable (program service expense/total expense) within organizations over time. In fact, this is not the case. For example, although the median percentage change in this performance measure over the 5 years is zero, the percentage change at the 10th percentile of changes is -0.094 and at the 90th percentile of changes is 0.099 .
} 
results in the tables). Only two of the individual industries show significantly positive returns on the fraction of expenses spent on program services. There is only a very weak link between pay and performance based on this measure. Nonprofits that spend higher fractions of their total expenses on actual program services tend to pay their top officers, directors, and trustees and top nonofficer, nondirector, and nontrustee staff more in the cross section, but further analysis suggests that this result is not particularly robust.

While, clearly, success in fund raising may be an important metric by which to evaluate managers of nonprofits, another possible measure of performance could be the combination of government grants and direct and indirect support from the public. The results of this investigation are reported for the two types of managers in Table 7 . In this case, even conditional on assets of the organization and with controls for NTEE industries or organization indicators, the higher the outside fund raising, the higher is the pay of the manager.

There is a host of other potential ways to measure performance in nonprofits. These include nonprofit profits, defined as total revenue minus expenses (median level in this sample \$1,117,222), and return on assets, defined as profits/assets (median level in this sample 7.01 percent). However, from an empirical point of view, neither of these measures is really related to compensation of the managers of the nonprofits. This may be due to the fact

\section{TABLE 7}

Managerial Pay and Performance in Nonprofit Organizations:

Performance Measured as Log of the sum of Government Grants, Public Direct Support, and Public Indirect Support

\begin{tabular}{|c|c|c|c|c|c|c|}
\hline & \multicolumn{6}{|c|}{ Dependent variable: $\ln ($ base pay + benefits + expense account $)$} \\
\hline & \multicolumn{3}{|c|}{ For top officer/director/trustee } & \multicolumn{3}{|c|}{$\begin{array}{l}\text { For top nonofficer/nondirector/ } \\
\text { nontrustee employee }\end{array}$} \\
\hline & (1) & (2) & (3) & (4) & $(5)$ & (6) \\
\hline Log (grants + support) & $\begin{array}{l}0.026^{* * * *} \\
(0.003)\end{array}$ & $\begin{array}{l}0.064 * * * \\
(0.003)\end{array}$ & $\begin{array}{l}0.011 * * \\
(0.004)\end{array}$ & $\begin{array}{l}-0.015^{* * *} \\
(0.002)\end{array}$ & $\begin{array}{l}0.046^{* * *} \\
(0.002)\end{array}$ & $\begin{array}{l}0.006 * * \\
(0.003)\end{array}$ \\
\hline Ln(assets) & $\begin{array}{l}0.206^{* * * *} \\
(0.003)\end{array}$ & $\begin{array}{l}0.169 * * * \\
(0.004)\end{array}$ & $\begin{array}{l}0.034^{* * * *} \\
(0.010)\end{array}$ & $\begin{array}{l}0.193^{* * * *} \\
(0.003)\end{array}$ & $\begin{array}{l}0.148^{* * *} \\
(0.003)\end{array}$ & $\begin{array}{l}0.016^{* *} \\
(0.007)\end{array}$ \\
\hline NTEE indicators & No & Yes & No & No & Yes & No \\
\hline Org. indicators & No & No & Yes & No & No & Yes \\
\hline$R^{2}$ & 0.163 & 0.204 & 0.789 & 0.213 & 0.356 & 0.835 \\
\hline$N$ & 28051 & 28051 & 28051 & 22719 & 22719 & 22719 \\
\hline
\end{tabular}

NotE: Support is the sum of public direct support and public indirect support. Standard errors are in parentheses. $*, * *$, and $* * *$ represent significance at the $0.10,0.05$, and 0.01 levels, respectively. Yearly indicators are included in all regressions.

SOURCE: IRS Tax Form 990 for individual organizations, years 1992-1996. 
that there are wide differences in the missions of most nonprofits. In the end, the measures of nonprofit size (including net ending assets) ${ }^{17}$ seem most appropriate as measures of performance.

As an additional examination of the issue of performance in nonprofits, I analyze (but do not report in the tables) the issue of relative performance evaluation [see Antle and Smith (1986) and Gibbons and Murphy (1990) for a discussion of relative performance evaluation in for-profit firms]. In this analysis I estimated empirical specifications much like those in Table 6 with the additional covariate of average performance (program service expense/ total expense) in that organization's industry (defined as one of the 26 NTEE industries detailed in the left hand column of Table 3). I find no evidence of relative performance evaluation for top managers in nonprofits. While performance by some metric may matter (although the results are not particularly robust) for the pay of managers in nonprofits, there is no evidence that it is measured relative to others.

\section{Government Grants and the Pay of Managers in Nonprofits}

All 501c(3) nonprofits "are entitled to receive tax-deductible contributions and are defined by the IRS as 'charitable' because they serve broad policy purposes" (Stevenson, Pollak, and Lampkin 1997). Considerable work has been done on issues of government crowd-out with regard to donations. ${ }^{18}$ From a conceptual point of view, government grants may mean one of several different things for the pay of managers of nonprofits. First, they could be a sign of organizational quality or managerial ability. That is, in the cross section, we might expect that those organizations with grants or those with larger grants should have managers who are paid more. However, within organizations (where industry type, organization quality, and managerial ability are fixed), more government grants may be a sign of some sort of outside monitoring of the manager or an increase in funding attracted by the manager. ${ }^{19}$

These ideas suggest the following simple modification of the earlier equation:

\footnotetext{
${ }^{17}$ As stated earlier, other measures of organization size, such as revenues, yield very similar results.

${ }^{18}$ For example, Rose-Ackerman (1987) studies issues related to whether government grants served as substitutes for private donations from a theoretical point of view.

${ }^{19}$ Others also may monitor the actions of managers in nonprofits such as donors and volunteers. Each of these constituents has an important stake in the organization. Unfortunately, data are not available to explore these issues empirically in this article.
} 


$$
C_{i t}=S_{i t} \gamma+G_{i t} \lambda+\alpha_{i}+e_{i t}
$$

And this includes the addition of government grants $G_{i t}$. I describe the precise definition of $G_{i t}$ below. Regressions of this form are reported in Table 8. The first three columns are for the compensation of the top officer, director, or trustee, and the last three are for the compensation of the top nonofficer, nondirector, or nontrustee. The top panel defines $G_{i t}=1$ if there is any government grant and 0 otherwise, and the bottom panel defines $G_{i t}=\log$ (grant size in dollars) for all organizations with positive grants. In column 1 of Table 8 , panel A, the $\log$ of total compensation of the top

TABLE 8

Government Grants and Managerial Pay in Nonprofits

\begin{tabular}{|c|c|c|c|c|c|c|}
\hline \multicolumn{7}{|c|}{ Panel A: Examination of the existence of a government grant in a nonprofit } \\
\hline & \multicolumn{6}{|c|}{ Dependent variable: $\ln ($ base pay + benefits + expense account $)$} \\
\hline & \multicolumn{3}{|c|}{ For top officer/director/trustee } & \multicolumn{3}{|c|}{$\begin{array}{l}\text { For top nonofficer/nondirector } \\
\text { nontrustee employee }\end{array}$} \\
\hline & (1) & $(2)$ & (3) & (4) & $(5)$ & $(6)$ \\
\hline $\begin{array}{l}\text { Government grant } \\
\quad(\text { Any grant }=1)\end{array}$ & $\begin{array}{l}0.165^{* * *} \\
(0.011)\end{array}$ & $\begin{array}{l}0.213 * * * \\
(0.011)\end{array}$ & $\begin{array}{l}-0.007 \\
(0.016)\end{array}$ & $\begin{array}{l}-0.015 \\
(0.007)\end{array}$ & $\begin{array}{l}0.125^{* * *} \\
(0.007)\end{array}$ & $\begin{array}{l}0.003 \\
(0.011)\end{array}$ \\
\hline $\operatorname{Ln}$ (assets) & $\begin{array}{l}0.213 * * * \\
(0.003)\end{array}$ & $\begin{array}{l}0.199 * * * \\
(0.003)\end{array}$ & $\begin{array}{l}0.047 * * * \\
(0.009)\end{array}$ & $\begin{array}{l}0.174 * * * \\
(0.003)\end{array}$ & $\begin{array}{l}0.156^{* * *} \\
(0.002)\end{array}$ & $\begin{array}{l}0.011^{*} \\
(0.006)\end{array}$ \\
\hline NTEE indicators & No & Yes & No & No & Yes & No \\
\hline Org. indicators & No & No & Yes & No & No & Yes \\
\hline$R^{2}$ & 0.143 & 0.181 & 0.797 & 0.180 & 0.319 & 0.829 \\
\hline$N$ & 32146 & 32146 & 32146 & 25197 & 25197 & 25197 \\
\hline
\end{tabular}

Panel B: Examination of the size of the government grant

\begin{tabular}{|c|c|c|c|c|c|c|}
\hline & \multicolumn{6}{|c|}{ Dependent variable: $\ln ($ base pay + benefits + expense account $)$} \\
\hline & \multicolumn{3}{|c|}{ For top officer/director/trustee } & \multicolumn{3}{|c|}{$\begin{array}{l}\text { For top nonofficer/nondirector/ } \\
\text { nontrustee employee }\end{array}$} \\
\hline & (1) & $(2)$ & (3) & (4) & $(5)$ & $(6)$ \\
\hline $\begin{array}{l}\text { Ln(value of government } \\
\text { grant) }\end{array}$ & $\begin{array}{l}0.036 * * * \\
(0.003)\end{array}$ & $\begin{array}{l}0.046^{* * *} \\
(0.003)\end{array}$ & $\begin{array}{l}0.009 \\
(0.007)\end{array}$ & $\begin{array}{l}0.040 * * * \\
(0.003)\end{array}$ & $\begin{array}{l}0.062 * * * \\
(0.002)\end{array}$ & $\begin{array}{l}0.005 \\
(0.004)\end{array}$ \\
\hline $\operatorname{Ln}($ assets $)$ & $\begin{array}{l}0.201 * * * \\
(0.004)\end{array}$ & $\begin{array}{l}0.184 * * * \\
(0.004)\end{array}$ & $\begin{array}{l}0.031 * * \\
(0.014)\end{array}$ & $\begin{array}{l}0.184 * * * \\
(0.003)\end{array}$ & $\begin{array}{l}0.164 * * * \\
(0.003)\end{array}$ & $\begin{array}{l}0.016^{*} \\
(0.009)\end{array}$ \\
\hline NTEE indicators & No & Yes & No & No & Yes & No \\
\hline Org. indicators & No & No & Yes & No & No & Yes \\
\hline$R^{2}$ & 0.218 & 0.246 & 0.765 & 0.252 & 0.426 & 0.872 \\
\hline$N$ & 13043 & 13043 & 13043 & 11307 & 11307 & 11307 \\
\hline
\end{tabular}

NotE: Standard errors are in parentheses. *,**, and *** represent significance at the $0.10,0.05$, and 0.01 levels, respectively. Yearly indicator variables are included in all regressions.

SOURCE: IRS Tax Form 990 for individual organizations, years 1992-1996. 
manager is regressed on an indicator for whether a government grant exists, a constant, a measure of organization size (log assets), and a set of yearly time indicators. The coefficient 0.165 suggests that organizations that have government grants pay their managers on average 17 percent more than those which do not have grants. Once individual organization fixed effects are controlled for in column 3 of Table 8, panel A, the effect of grants is slightly negative (but not significant). ${ }^{20}$ Roughly the same results come out of similar analyses in the rest of the panel. ${ }^{21}$

This suggests that in the cross section, organizations that receive grants pay their managers more but that within organizations (i.e., once organizational quality or managerial ability are fixed) managers with grants may be paid the same or slightly less. That is, within an organization, adding a grant does not increase and actually may decrease managerial pay. ${ }^{22}$

Managers of nonprofits are paid more on average when they generate grants, but this is not true within organizations. Clearly, certain kinds of organizations that pay managers well generate relatively large amounts of grant money. However, top managers in nonprofits are not additionally compensated when their organizations generate new (or additional) government grants.

\section{Governance in Nonprofits: The Role of Boards in Managerial Pay}

There is some evidence that the makeup of the board of directors may have some influence on managerial pay or turnover in for-profit firms (e.g., Weisbach 1988; Main, O'Reilly, and Wade 1995; and Hallock 1997, 1999). Despite some excellent work in the area (e.g., Bowen 1994), little is known about governance in nonprofit organizations, and even less is known about the compensation structure for the managers who lead these organizations. This section contains an investigation of the effects of board structure on the compensation of managers and top employees in nonprofits.

Hallock (1997) presents cross-sectional results that show that, controlling for the levels of assets, stock performance, and CEO characteristics, CEOs

\footnotetext{
${ }^{20}$ The chi-square value of the Hausman test of the fixed-effects specification in Table 8 versus the random effects specification is highly significant $(p<0.001)$ and indicates that inferences based on the specifications reported in Table 8 are most appropriate.

${ }^{21}$ Since the definition of government grants in panel B of Table 8 drops 59 percent of the observations, a referee suggested that I instead use $\log$ (value of government grants +1$)$ as the main independent variable in this model. If I recomputed the analysis in this way, the qualitative results are similar, the significance levels remain the same, and all coefficients are reduced in absolute value.

${ }^{22}$ See Tosi and Gomez-Mejia (1989, 1994), Gomez-Mejia, Tosi, and Hinkin (1987), Zajac and Westphal (1994), and Hallock (1997) for related literature in firms.
} 
who lead for-profit firms with larger boards earn more. However, nonprofit organizations are different in many ways, and their boards may be serving a different function (Bowen 1994). Perhaps larger boards suggest that there is more monitoring, and therefore, lower-quality managers are needed or at least managers who are paid less.

Table 9 presents the results from regressions of a similar form as in the preceding tables with the addition of a variable on the number of board directors in the nonprofit organization. The results for the top officer, director, or trustee are reported in the first three columns and for the top

TABLE 9

The Effect of Board Composition on Managerial Pay in Nonprofits

\begin{tabular}{|c|c|c|c|c|c|c|}
\hline \multicolumn{7}{|c|}{ Panel A: Board size measured by number of paid directors } \\
\hline & \multicolumn{6}{|c|}{ Dependent variable: $\ln ($ base pay + benefits + expense account $)$} \\
\hline & \multicolumn{3}{|c|}{ For top officer/director/trustee } & \multicolumn{3}{|c|}{$\begin{array}{l}\text { For top nonofficer/nondirector/ } \\
\text { nontrustee employee }\end{array}$} \\
\hline & (1) & $(2)$ & (3) & (4) & $(5)$ & (6) \\
\hline Number of paid directors & $\begin{array}{l}-0.007 * * * \\
(0.001)\end{array}$ & $\begin{array}{l}-0.012^{* * *} \\
(0.001)\end{array}$ & $\begin{array}{l}-0.011^{* * *} \\
(0.001)\end{array}$ & $\begin{array}{l}0.015^{* * *} \\
(0.001)\end{array}$ & $\begin{array}{l}0.010 * * * \\
(0.001)\end{array}$ & $\begin{array}{l}-0.004 * * * \\
(0.001)\end{array}$ \\
\hline $\operatorname{Ln}$ (assets) & $\begin{array}{l}0.223 * * * \\
(0.003)\end{array}$ & $\begin{array}{l}0.215^{* * *} \\
(0.004)\end{array}$ & $\begin{array}{l}0.050^{* * *} \\
(0.009)\end{array}$ & $\begin{array}{l}0.160^{* * *} \\
(0.002)\end{array}$ & $\begin{array}{l}0.151 * * * \\
(0.002)\end{array}$ & $\begin{array}{l}0.012^{* *} \\
(0.006)\end{array}$ \\
\hline NTEE indicators & No & Yes & No & No & Yes & No \\
\hline Org. indicators & No & No & Yes & No & No & Yes \\
\hline$R^{2}$ & 0.138 & 0.175 & 0.796 & 0.186 & 0.317 & 0.829 \\
\hline$N$ & 32146 & 32146 & 32146 & 25197 & 25197 & 25197 \\
\hline
\end{tabular}

Panel B: Board size measured by number of unpaid directors

\begin{tabular}{|c|c|c|c|c|c|c|}
\hline & \multicolumn{6}{|c|}{ Dependent variable: $\ln ($ base pay + benefits + expense account $)$} \\
\hline & \multicolumn{3}{|c|}{ For top officer/director/trustee } & \multicolumn{3}{|c|}{$\begin{array}{l}\text { For top nonofficer/nondirector/ } \\
\text { nontrustee employee }\end{array}$} \\
\hline & $(1)$ & $(2)$ & (3) & (4) & (5) & $(6)$ \\
\hline Number of unpaid directors & $\begin{array}{l}0.004 * * * \\
(0.0002)\end{array}$ & $\begin{array}{l}0.004 * * * \\
(0.0002)\end{array}$ & $\begin{array}{l}0.0002 \\
(0.0002)\end{array}$ & $\begin{array}{l}-0.001 * * * \\
(0.0001)\end{array}$ & $\begin{array}{l}0.0004 * * * \\
(0.0001)\end{array}$ & $\begin{array}{l}-0.0002 \\
(0.0001)\end{array}$ \\
\hline Ln(assets) & $\begin{array}{l}0.210^{* * *} \\
(0.003)\end{array}$ & $\begin{array}{l}0.195^{* * *} \\
(0.003)\end{array}$ & $\begin{array}{l}0.047^{* * *} \\
(0.009)\end{array}$ & $\begin{array}{l}0.176^{* * *} \\
(0.002)\end{array}$ & $\begin{array}{l}0.159^{* * * *} \\
(0.002)\end{array}$ & $\begin{array}{l}0.011^{*} \\
(0.006)\end{array}$ \\
\hline NTEE indicators & No & Yes & No & No & Yes & No \\
\hline Org. indicators & No & No & Yes & No & No & Yes \\
\hline$R^{2}$ & 0.147 & 0.185 & 0.797 & 0.183 & 0.310 & 0.829 \\
\hline$N$ & 32146 & 32146 & 32146 & 25197 & 25197 & 25197 \\
\hline
\end{tabular}

NotE: Standard errors are in parentheses. * ${ }^{* *}$, and $* * *$ represent significance at the $0.10,0.05$, and 0.01 levels, respectively. Yearly indicators are included in all regressions.

SOURCE: IRS Tax Form 990 for individual organizations, years 1992-1996. 
nonofficer, nondirector, or nontrustee employee in the last three. Panel A reports results on the link between managerial pay and the number of paid board members, whereas panel B reports results on the link between managerial pay and the number of unpaid directors.

Some researchers including, Main, O'Reilly, and Wade (1993) have tested tournaments (Lazear and Rosen 1981) in large for-profit firms by including the number of vice presidents in a standard CEO pay regression. The idea is that, conditional on other factors, CEO pay should be higher in the presence of more vice presidents because more individuals are in competition for the top spot in the firm. In the case of this article, however, board members are not as likely as vice presidents in for-profit firms to compete for the top position, so the tournament theory is not necessarily testable in this way in nonprofits. ${ }^{23}$

Panel A of Table 9 shows that the larger the board, the less the top officer, director, or trustee is paid. This is true even when controlling for 26 NTEE classifications (column 2) and for individual organization fixed effects (column 3). For the top nonofficer, nondirector, or nontrustee employee, in the simple cross section and when controlling for 26 NTEE industry effects, the larger the board, the higher is the pay of the employee. However, when individual organization fixed effects are controlled for, the same negative result (larger board, less pay) appears. The results are less robust in panel B of Table 9 when the effect of unpaid directors is examined.

Again, the results in this section are not entirely clear. Perhaps board members serve as substitutes for management experience. Therefore, as board sizes grow, there is less need for a highly paid top officer, director, or trustee or nonofficer, nondirector, or nontrustee employee because larger paid boards may be able to more easily manage organizations than smaller boards. Another explanation may be that it is easier for larger boards to monitor the operations of organizations, and therefore, organizations with larger boards may not require managers with high salaries. The differing results for the unpaid/paid members suggests that a more detailed examination of the effects of boards on managerial pay in nonprofits would be interesting.

\section{Concluding Comments}

There is an expansive theoretical and empirical body of work on the compensation of managers of firms in the United States (e.g., Murphy 1999)

\footnotetext{
${ }^{23}$ Main, O'Reilly, and Wade (1993) also show further support for tournament theory in for-profit firms in that the larger the firm, the larger is the pay gap at the top.
} 
and some basic theoretical work on compensation in nonprofits that can be applied to managers of nonprofit organizations. However, little is known about the compensation of managers of nonprofits from an empirical point of view. This article presents evidence on the compensation of top managers of nonprofits in the United States using a very large amount of previously unexplored data from tax returns of the organizations.

Among the main empirical findings are that pay levels of top officers and directors of charities average about $\$ 160,000$, not close to those reported for heads of large U.S. firms. Just as there is a well-documented link between organization size and managerial pay in for-profit firms, there is a similar relationship in nonprofits. Also, there is substantial variability in the pay of top managers of charities, within the charities and across types of charities, as defined by their NTEE industries. In addition, a reasonably large fraction of the compensation of top officers, directors, and trustees and of top nonofficer, nondirector, or nontrustee employees comes in the form of benefit plans and expense accounts. It is also the case that although in the simple cross section nonprofits with higher levels of government grants pay their heads more, this is not true once organization fixed effects are accounted for. This may be due to the fact that government agencies monitor managerial actions, and managers can be paid less in the presence of this monitoring. Similarly, there is a weak negative relationship between the number of paid board members and managerial pay in nonprofits, suggesting, perhaps, that paid boards of directors substitute for managerial talent.

Recently, there has been increased emphasis on the compensation and governance of managers in nonprofits (e.g., Taxpayer Bill of Rights 2 1996). However, very little is known about the pay of these managers. 501c(3) nonprofits seem to be a relatively narrow set of organizations. However, one possibility is that they actually perform significantly different tasks and therefore are organized quite differently from one another. This may lead, in turn, to differences in the way they pay their managers. This article is an important first step in studying the pay of managers in these types of organizations. Hopefully, these basic findings can help inform the issues and motivate further research in the area.

\section{REFERENCES}

Abelson, Reed. 1998. "Nonprofit Work Gets Profitable.” New York Times,” Sunday March 29.

Agarwal, Naresh L. 1981. "Determinants of Executive Compensation." Industrial Relations 20 (Winter):36-46.

Antle, Rick, and Abbie Smith. 1986. "An Empirical Investigation of the Relative Performance Evaluation of Corporate Executives." Journal of Accounting Research 24(Spring):1-39. 
Bertrand, Marianne, Kevin F. Hallock, and Richard Arnould. 2000. "Does Managed Care Change the Mission of Nonprofit Hospitals? Evidence from the Managerial Labor Market." Working paper no. 7924," Cambridge, MA.

Bowen, William, G. 1994. Inside the Boardroom. New York: Wiley.

—- Thomas Nygren, Sarah E. Turner, and Elizabeth A. Duffy. 1994. The Charitable Nonprofits: An Analysis of Institutional Dynamics and Characteristics. San Francisco: Jossey-Bass Publishers.

Council of Better Business Bureaus. Undated. CBBB Standards for Charitable Solicitations. Arlington, VA: CBBB.

Ehrenberg, Ronald G., John J. Cheslock, and Julia Epifantseva. 2000. "Paying Our Presidents: What Do Trustees Value?" NBER Working Paper No. 7886, Cambridge, MA.

Finkelstein, Sydney, and Donald Hambrick. 1989. "Chief Executive Compensation: A Study of the Intersection of Markets and Political Processes." Strategic Management Journal 10(MarchApril):121-34.

and - 1996. Strategic Leadership: Top Executives and Their Effect on Organizations. New York: West Publishing.

Gibbons, Robert, and Kevin J. Murphy. 1990. "Relative Performance Evaluation for Chief Executive Officers," Industrial and Labor Relations Review 43(February):30S-51S.

Gomez-Mejia, Luis, Henry Tosi, and Timothy Hinkin. 1987. "Managerial Control, Performance, and Executive Compensation." Academy of Management Journal 30(March):51-70.

Gronbjerg, Kristin A. 1994. "Using NTEE to Classify Non-profit Organizations: An Assessment of Human Service and Regional Applications." Voluntas 5(3):301-28.

Hallock, Kevin F. 1997. "Reciprocally Interlocking Boards of Directors and Executive Compensation." Journal of Financial and Quantitative Analysis 32(September):331-44.

. 1999 "Dual Agency: Corporate Boards with Reciprocally Interlocking Relationships." In Executive Compensation and Shareholder Value: Theory and Evidence, edited by Jennifer Carpenter and David Yermack, pp. 55-75. Dorrecht, The Netherlands: Kluwer.

Hansmann, Henry B. 1980. "The Role of Nonprofit Enterprise." Yale Law Journal 89(April):835-98.

- 1996. The Ownership of Enterprise. Boston: Harvard University Press.

Hodgkinson, Virginia A. 1990. "Mapping the Nonprofit Sector in the United States: Implications for Research." Voluntas 12(2):6-32.

— and Christopher M. Toppe. 1991. "A New Research and Planning Tool for Managers: The National Taxonomy of Exempt Entities." Nonprofit Management and Leadership 1(Summer):40314.

Internal Revenue Service. 1996. Instructions to Form 990. Washington: IRS.

James, Estelle, and Susan, Rose-Ackerman. 1986. The Nonprofit Enterprise in Market Economies. New York: Harwood Academic Publishers.

Jensen, Michael, and Kevin J. Murphy. 1990. "Performance Pay and Top Management Incentives." Journal of Political Economy 98(April):225-64.

Joskow, Paul, Nancy Rose, and Andrea Shepherd. 1993. "Regulatory Constraints on CEO Compensation." Brookings Papers on Economic Activity: Microeconomics 1:1-58.

Kostiuk, Peter F. 1990. "Firm Size and Executive Compensation." Journal of Human Resources 25(Winter):90-105.

Lambert, Richard A., David F. Larker, and Keith Weigelt. 1991. "How Sensitive is Executive Compensation to Organization Size." Strategic Management Journal 12(July):395-402.

Lazear, Edward P. 1995. Personnel Economics. Cambridge, MA. MIT Press. - and Sherwin Rosen. 1981. "Rank Order Tournaments as Optimum Labor Contracts.” Journal of Political Economy 89(October):841-64.

Main, Brian G. M., Charles A. O’Reilly III, and James Wade. 1993. "Top Executive Pay: Tournament or Teamwork?" Journal of Labor Economics 11(October):606-8. - — , and 1995. "The CEO, the Board of Directors, and Executive Compensation: Economic and Psychological Perspectives." Industrial and Corporate Change 4:293-32.

Mirvis, P. H., and E. J. Hackett. 1983. "Work and Work Force Characteristics in the Nonprofit Sector." Monthly Labor Review 106(April):3-12. 
Murphy, Kevin J. 1985. "Corporate Performance and Managerial Remuneration: An Empirical Analysis." Journal of Accounting and Economics 7(April):11-42.

1999. "Executive Compensation". In Handbook of Labor Economics, Vol. 3B, edited by Orley Ashenfelter and David Card, pp. 2485-2563. Amsterdam: North-Holland.

Oster, Sharon. 1998. "Executive Compensation in the Nonprofit Sector." Nonprofit Management and Leadership 8(Spring):207-21.

Preston, Anne. 1989. "The Nonprofit Worker in a For-Profit World." Journal of Labor Economics 7 (October):438-3.

- 1990. "Women in the White-Collar Nonprofit Sector: The Best Option or the Only Option?" Review of Economics and Statistics 72(November):560-8.

—. 1994. "Women in the Nonprofit Labor Market." In Women and Power in the Nonprofit Sector, edited by T. Odendahl and M. O'Neil, pp. 39-77. San Francisco: Jossey-Bass.

Rose-Ackerman, Susan. 1987. "Ideals versus Dollars: Donors, Charity Managers, and Government Grants." Journal of Political Economy 95(August):810-23.

Rosen, Sherwin. 1992. "Contracts and the Market for Executives. In Main Currents in Contract Economics, edited by L. Werin and H. Wijkander, pp. 181-211. Oxford, England: Blackwell.

Salamon, Lester M. 1992. America's Nonprofit Sector: A Primer. New York: The Foundation Center.

Steinberg, Richard. 1990a. "Labor Economics and the Nonprofit Sector: A Literature Review." Nonprofit and Voluntary Sector Quarterly 19(Summer):151-70.

- 1990b. "Profits and Incentive Compensation in Nonprofit Firms." Nonprofit Management and Leadership 1(Winter):137-52.

Stevenson, David R., Thomas H. Pollak, and Linda M. Lampkin (with Kathryn L. S. Pettit and Nicholas A. J. Stengel). 1997. State Nonprofit Almanac 1997: Profiles of Charitable Organizations. Washington: Urban Institute Press.

Taxpayer Bill of Rights 2, July 30, 1996, Public Law 104-168, Internal Revenue Service.

Tosi, Henry L., Jr., and Luis R. Gomez-Mejia. 1989. "The Decoupling of CEO Pay and Performance: An Agency Theory Perspective." Administrative Science Quarterly 34(June):169-89.

and - 1994. "CEO Compensation Monitoring Firm Performance." Academy of Management Journal 37(August):1002-16.

Turner, Sarah E., Thomas I. Nygren, and William G. Bowen. 1992. "The NTEE Classification System: Tests of Reliability in the Field of Higher Education." Voluntas 4(1):73.

Weisbach, Michael. 1988. "Outside Directors and CEO Turnover." Journal of Financial Economics 20(January-March):431-60.

Weisbrod, Burton A. 1983. "Nonprofit and Proprietary Sector Behavior: Wage Differentials Among Lawyers." Journal of Labor Economics 1(July):246-63.

. 1989. "Rewarding Performance That is Hard To Measure: The Private Nonprofit Sector." Science 244(5):541-6.

and Mark Schlesinger. 1986. "Public, Private, Nonprofit Ownership and the Response to Asymmetric Information: The Case of Nursing Homes." In The Economics of Nonprofit Institutions: Studies in Structure and Policy, edited by Susan Rose-Ackerman, pp. 133-51. New York: Oxford University Press.

Westphal, James D., and Edward J. Zajac. 1994. "Substance and Symbolism in CEO's Long-Term Incentive Plans." Administrative Science Quarterly 39(September):367-90.

Young, Dennis R. 1984. "Performance and Reward in Nonprofit Organizations: Evaluation, Compensation, and Personal Incentives." Yale Program on Nonprofit Organizations Working Paper No. 79. New Haven.

Zajac, Edward J., and James D. Westphal. 1994. "The Costs and Benefits of Managerial Incentives and Monitoring in Large U.S. Corporations: When More Is Not Better?" Strategic Management Journal 15(Winter):121-42. 